\title{
HISTORICAL DEVELOPMENT OF DADO ORNAMENTATION IN MUGHAL ARCHITECTURE
}

\author{
FARAH JAMIL \& SAIMA GULZAR \\ School of Architecture and Planning, University of Management and Technology, Pakistan
}

\begin{abstract}
Mughals being passionate for art and architecture developed new styles and technology for the ornamentation and design of their remarkable buildings. Mughal monuments are known for their characteristic architectural ornamentation which reflects their artistic sense and refined taste for architecture. Ornamentation in Mughal buildings is found to be the fusion of Iranian, Persian, Indian and Islamic architectural style. The aim of this paper is to emphasize the feature of wall decoration, especially dado art, as being a prominent part of decoration and its transitional development during different Mughal periods. It is an attempt to find the influences and their impacts during different reigns of Mughal emperors on the ornamentation style of Mughal buildings. This comprehensive study investigates the history of the transition of design, techniques and materials in chronological order of Mughal Buildings; that is, the combination of Persian, Indian and Islamic art forms which were used as a part of interior as well as exterior wall decoration. The study also reveals the variation in motif design used for wall decoration in different squares and rectangular portions of buildings throughout Mughal architecture.
\end{abstract}

Keywords: Mughals, art, ornamentation, dado, Islamic.

\section{INTRODUCTION}

Mughal monuments are famous for their monumental and ornamented architecture which have left the stamp of a magnificent Mughal era having characteristic tastes, beliefs, values, ideals and interests, as stated by Brown [1]. The essential character of Mughal architecture is the architectural ornamentation in their buildings. Nath [2] reported that External and internal wall decorations employed in different religious places, forts, mausoleums has a unique place in this context. Dadoes were considered as an integral part of decorating lower walls of internal and external surfaces. Baldry [3] inferred that Mughals used many types of motifs as animated, natural, geometric, and abstract for wall decoration in exteriors as well as in interiors. Dadoes are described as lower part of the walls. In architectural terminology, it is the part given a decorative treatment to cover the lower part of the wall usually subjected to stains associated with dampness and furniture.

Mughals employed different decorative arts in their own characteristic style including painting, tile decoration, mosaic painting, stucco, stone carving, incised and inlay for the ornamentation of dadoes in Sharma [4]. According to Beach and Chandra [5] the inspiration of Mughal dado art came from the miniature paintings which imitated the works of Persian artists at various places in the Indian subcontinent.

\section{RESEARCH METHODOLOGY}

The research is mainly focused on descriptive and historical approach that is based on the studies of Mughal architecture as it evolved under succession of emperors beginning with Babur, continuing with Akbar, Jahangir and Shah Jahan and concluding with the reign with Aurangzeb. The objective was to collect data through books and physical surveys regarding the ornamentation of dadoes from most of the important surviving monuments of Mughal architecture to generate the vocabulary of dado ornamentation in Mughal Architecture. One of the aims of this study was also to analyze the evolution and transitional changes in dado 
ornamentation from monochromatic to polychromatic approach of ornamenting and treating building surfaces during the magnificent Mughal era. This paper also focuses on the building materials, color and technique used in ornamentation of buildings that attributed characteristic expression of Mughals in their architecture.

\section{RESULTS AND DISCUSSIONS}

Mughal architecture in the Indian subcontinent started with the Persian influence blended into the local traditional architecture but developed by a progressive sequence into a characteristically Mughal style that survived over the centuries revealed through Smith [6].

Babur brought two Persian artists with him as result of a battle between Ibrahim Lodi (the last of the afghan kings) and Babur. They continued their art work even after the death of Babur. Akbar his son when came into power, the tradition of employing artist from abroad continued. Their work was much inspired from Persian art. In Persian and Mughal dado art ornamentation, gardens were the favorite subject which became source of inspiration for the artists. Nature was considered as an integral part of interior decoration as stated in Nath [7]. They were of the view that if a person thinks himself with nature he can find new strength and art of life. The gardens and floral arrangement were in square shape so that is why it is clearly seen dadoes in rectangular and square forms. Mural or dado decoration is usually done on walls of buildings which used to be prominent features of castles, palaces, and mosques. These include tile decoration, mosaic painting, stucco, incised, inlay, carving in marble with high and low relief of dados. Tiled panels of dadoes in Lahore fort show distinct fusion of Chinese, Persian and Iranian influence. In Persian art the facial features of characters, combination of colors, style of ornamentation, use of animal figures and angels used in some of the panels presents familiarization to Persian miniature art like gateway of GulabiBagh (1655 AD) is an outstanding example of the rich and vibrant mosaic tile work in Persian style. Colors used in calligraphy as well as in glazed tile mosaic work like deep blue, yellow, green, turquoise and white all show Iranian influence on Pakistan during 15th and 17th century. For the very first time at Lahore Iranian decorative motifs like star shaped flowers, grapevine creeper, and cypress were used on the walls of Wazir khan Mosque. It was mainly because of Humayun when he returned to India he took two Iranian painters Mir Sayyid Ali and khawaja Abdus Samad with him who were later encouraged by his successor Akbar. It was under their guidance that by the end of 16th century Mughal Style formed as a result of Persia, Iranian and Chinese art forms (see Table 1).

\subsection{Characteristics of dado ornamentation under Babur period}

Gharipour and Schick [8] reported that the dado ornamentation style found during the Babar period was very simple and mainly with geometric designs in the Indian subcontinent.

\subsection{Characteristics of dado ornamentation under Humayun's period}

Mughal Empire was re-established by Humayun and so do the art and architecture also flourished. Persian influence seen in Mughal buildings is the result of Humayun's observance during his period of exile at the court of Shahtah Masp, as stated in Godard [9] (see Table 1). 


\subsection{Characteristics of dado ornamentation under Akbar period}

The history of Mughal Architecture starts with Akbar in true sense. Akbar built many forts, mausoleums palaces and mosques. To build up his empire he utilized local talent and took inspiration from traditional Hindu architectural features which are well depicted in the Akbari style of architecture during Akbar's reign the architectural examples shows a blend of Persian and Hindu influences. Gascoigne [10] reported that the main features of his buildings were the synthesis of Hindu Muslim art tradition and extensive use of red sandstone analyzed from the decorations of internal and external wall surfaces.

The building materials used in architecture of Akbar's time were red and yellow sandstone with the insertion of white marble boldly inlaid patterns are carved on internal and external wall surfaces seen on dadoes as well (see Table 1).

In Akbar's reign, Hindu auspicious motifs were used in the Mughal building to bring cultural fusion as an architectural element for aesthetic effect more than symbolic representation. Akbar invited the craftsman from all parts of India and employed them with full freedom to display their art. Characteristic works of Akbar include Agra fort, a vast structure first conceptualized of red sandstone on such a large scale which is one of the glorious examples of amalgamation of Hindu ad Islamic elements in Architecture.

The greatest achievement of Akbar was to set a new capital at Fatehpur Sikri. He built a remarkable city with three sides, surrounded by a wall with nine gates and the fourth side by an artificial lake. Entrance was from Agra gate. Fatehpur Sikri exhibits the most authentic record of the decorative motives of Hindu, Islamic as well as Chinese. The use of religious Hindu motifs and Chinese motifs can abundantly be found in Fatehpur Sikri as revealed through Nath [11]. The Swastika (Hindu solar symbol), as an ornamental motif with geometrical design was introduced in the monuments of Fatehpur Sikri. Carving on the borders of the dado panels at Sultan's House at Fatehpur Sikri shows swastika motifs beautifully enclose the natural vegetation composition of the dado.

\subsection{Characteristics of dado ornamentation under Jahangir's period}

Jahangir had a fine artistic sense and had more love and interest for miniature painting than in architecture. Jahangir et al. [12] stated that Mughal painting reaches its peak of accomplishment during Jahangir's period. Because of their beauty and aesthetic sense on miniatures Jahangir utilized this form of art on the dadoes of Mughal buildings in white marble panels. Plants, flowers, vines were generally used in the borders with carving or inlaying them with precious stones. It was under his reign the innovative practice of mounting hashiyas (borders) was used which showed an inspiration from Iran. These vegetal patterns, curves and arabesque scrolls show its great resemblance to Persian art and miniature painting. Borders with birds, butterflies and bright colored flowers became a distinctive feature of Mughal buildings (see Table 1).

According to Sarkar [13], Jahangir's period was known as a transitional period in the ornamentation of buildings as red sandstone was replaced by white marble; during Jahangir's period a technique of intarsia (interlocking of precious cut stones of different textures) was introduced to create patterns. Topaz, onyx, carnelian and lapis lazuli have been combined with marble to create designs of perfection.

Architectural trend during Jahangir's reign include noteworthy buildings like Tomb of Akbar at Sikandra and Mausoleum of Itmad-ud-Daula. The period of Jahangir marks a transition from monochromatic red sandstone to the simpler marble surfaces. These marked a major turning point in Mughal history as previously used sandstone compositions of 
Akbar's time were used in a new way, in luxurious masterpieces in Akbar's tomb. Akbar's tomb at Sikandra beautifies with the combination of white marble and red sandstone with their contrasting colors and textures mentioned in Klingelhofer [14]. As analyzed from visual surveys the wall surfaces indicate geometric and arabesque designs were followed in his reign, abri stars were in laid in geometrical oblong dado panels and also arrangement of square and rectangular pieces of multihued stones in floral patterns. The three surviving marble dadoes on the second-story hall of the western gateway are undoubtedly finest examples of dado art which are an example of usage of hashiyas (borders), beautifully inlaid borders in white marble. Each of the white marble borders on dado panel with floral motifs is defined by black marble to highlight it on the red sandstone surface. Similarly, inlaid borders are used on the dado panels of Itmad-ud-daula tomb with colored and textured patterns are created by white marble interlocking six pointed stars and figures with multi-pointed stars surrounded by diamond shaped elements.

\subsection{Characteristics of dado ornamentation under Shah Jahan period (the Reign of Marble)}

The Mughal style of architecture gained exceptional importance and splendor during Emperor Shah Jahan's reign. He was considered as one of the magnificent and creative builders among the Mughals. It was rendered as a golden age of Mughal Dynasty. He built numerous palaces, forts, mosques and mausoleums. Mughal architecture reached to the highest degree of perfection under Shah Jahan reign.

Mitchell and Currim [15] reported that during the era of Shah Jahan extensive use of marble became popular which projects dedication to Islamic faith and symbolizes sense of power. Structures built under his period used less expensive material. The single most important change was the substitute of marble for red sand stone. The white marble was sourced from 250 miles of quarries in Rajasthan. Rich decoration was achieved by change in technique by means of inlaid patterns in color stones as stated in Willis et al. [16]. Shah Jahan left a grand legacy of structures during his period. The architectural structures built by Shah Jahan were highly artistic in nature and rich in ornamentation. Rectangular shape of structures used in ornamental elements of previous age was replaced by curvilinear and flowing rhythmic patterns (see Table 1).

Some of the renowned buildings under Shah Jahan period include Taj Mahal and Moti Masjid in Agra. Taj Mahal considered as the famous and one of the recognizable structures of the world as a symbol of love and was built by him for his wife Mumtaz. Taj Mahal complex was designed on a theme to develop a house on earth for the departed soul. As studied from the pictures of Taj Mahal lower walls of the tomb have dadoes ornamentation which shows well balanced, perfectly proportioned and harmonization with its constructive design. Each of the chamber walls is highly decorated with intricate calligraphic panels and dado with expensive inlay or Parchin Kari work. Decorated with square dado panels with realistic bas relief and within these panels stylized floral motives of flower and plants, the pictures of trees, animal scenes were organized that resembled Mughal flower beds which symbolize its connection to nature reveled through Begley and Desai [17]. The marble has been polished to emphasize the carving on dado frames with lapidary of precious and semi-precious stones.

Moti masjid is a small mosque, completely clad in white marble is located inside Lahore fort. Moti is Urdu language word means pearl which symbolizes preciousness related to the religious structure. The interior of the mosque is simple with inlay works in white marble that was brought from Makrana. Building ornamentation on dado surfaces shows Italian derived technique of Petra Dura (technique of shipping and setting tiny pieces of many 
precious stones in marble) was considered as a hallmark of Shahjahan era. Architectural decoration which was on peak under Shahjahan's time symbolized wealth and power which Mughals gained in Shahjahan's time.

\subsection{Characteristics of dado ornamentation under Aurangzeb's period}

Aurangzeb Alamgir was known to rule the largest state of Muslims in the world. He ruled for more than fifty years. Mughal architecture and its ornamentation began to lose its character and vitality. According to Schimmel and Waghmar [18] the reign of Aurangzeb Alamgir was again a transitional period in which the material usage and trend shifted from white marble with a little use of red sandstone (see Table 1).

Foundations of Aurangzeb reign were based on Islam and sharia (Islamic law). During his reign many Hindu temples were defaced and destroyed because according to his interpretation Islam forbids the usage of images or figures. He stopped the usage representational artwork and Hindu inspired practices for ornamenting including miniature painting which reached to its peak before his rule revealed through Ebba [19].

Badshahi mosque located in Lahore is one of the unique examples of religious harmony and a significant monument built during Aurangzeb's reign. The interior of the mosque is richly ornamented with stucco tracery and paneling with frescoes and marble inlay. Dadoes on the exterior of the mosque are decorated with rich stone carving and marble inlay on red sandstone.

Table 1: Formulation of dado art in Mughal architecture.

\begin{tabular}{|c|c|c|c|c|}
\hline $\begin{array}{l}\text { Mughal } \\
\text { emperors }\end{array}$ & \begin{tabular}{|l|} 
Famous \\
buildings
\end{tabular} & Materials & Color & Photographs \\
\hline (2) & $\begin{array}{l}\text { Kabul Bagh at } \\
\text { Panipat, } \\
\text { Jamia Masjid } \\
\text { at Sambhal } \\
\text { and the } \\
\text { Takhat-I- } \\
\text { Babri at } \\
\text { KalarKahar }\end{array}$ & $\begin{array}{l}\text { Red } \\
\text { sandstone, } \\
\text { brick and } \\
\text { plaster }\end{array}$ & Monochromatic red & $\begin{array}{l}\text { Dadoes of Kabul Bagh Mosque at } \\
\text { Panipat. } \\
\text { (Source: } \\
\text { http://www.hoparoundindia.com/ha } \\
\text { ryana/attractions- } \\
\text { gallery/40556/Kabuli-Bagh- } \\
\text { Mosque.aspx\#1) }\end{array}$ \\
\hline
\end{tabular}


Table 1: Continued.

\begin{tabular}{|c|c|c|c|c|}
\hline $\begin{array}{l}\text { Mughal } \\
\text { emperors }\end{array}$ & $\begin{array}{l}\text { Famous } \\
\text { buildings }\end{array}$ & Materials & Color & Photographs \\
\hline 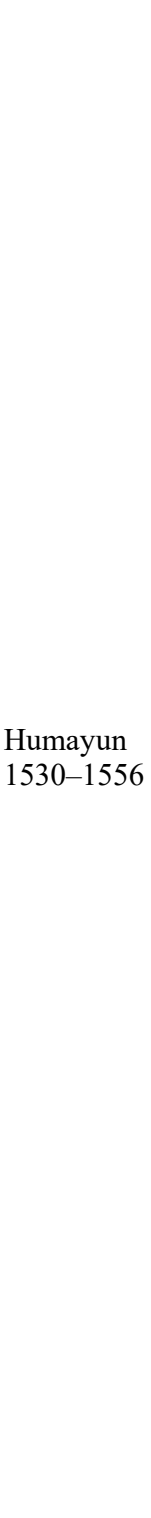 & $\begin{array}{l}\text { Humayun's } \\
\text { palace at } \\
\text { Dehli called } \\
\text { Din Panah. } \\
\text { Mosque at } \\
\text { Fatehbad in } \\
\text { the Hisar } \\
\text { district }\end{array}$ & $\begin{array}{l}\text { Red } \\
\text { sandstone, } \\
\text { brick and } \\
\text { plaster }\end{array}$ & Monochromatic red & 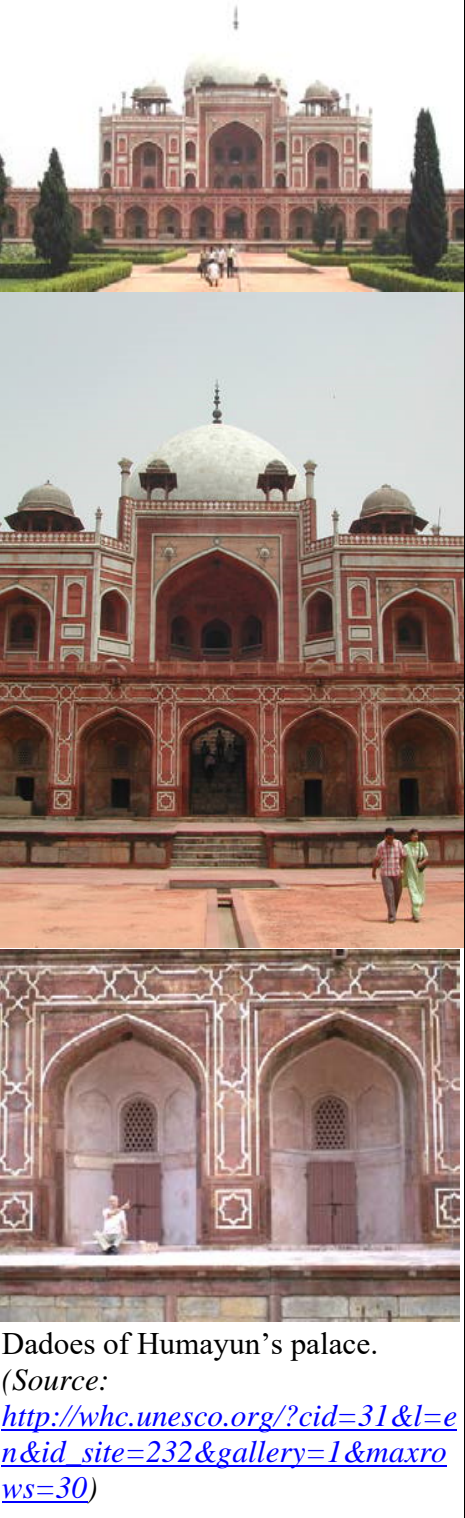 \\
\hline
\end{tabular}


Table 1: Continued.

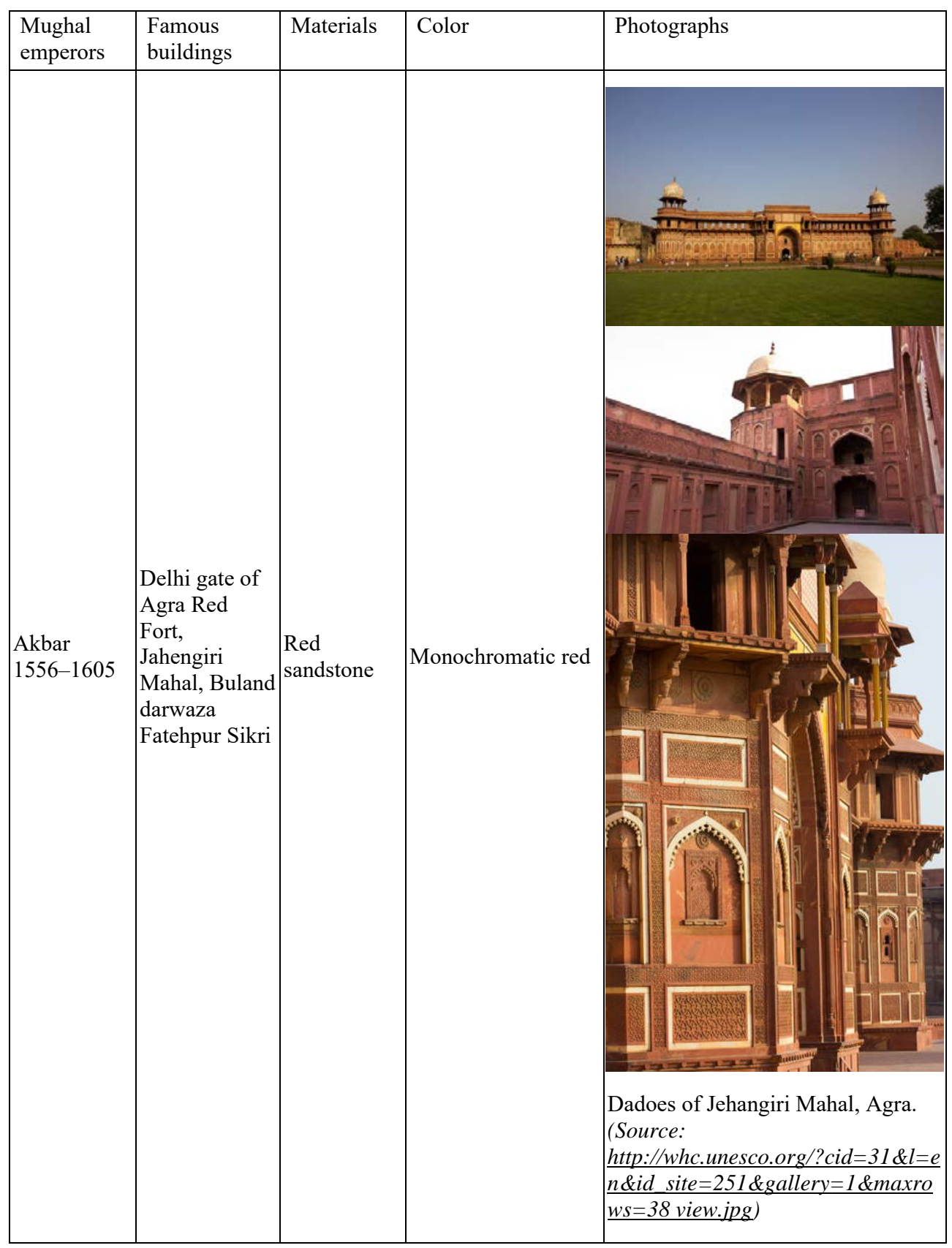


Table 1: Continued.

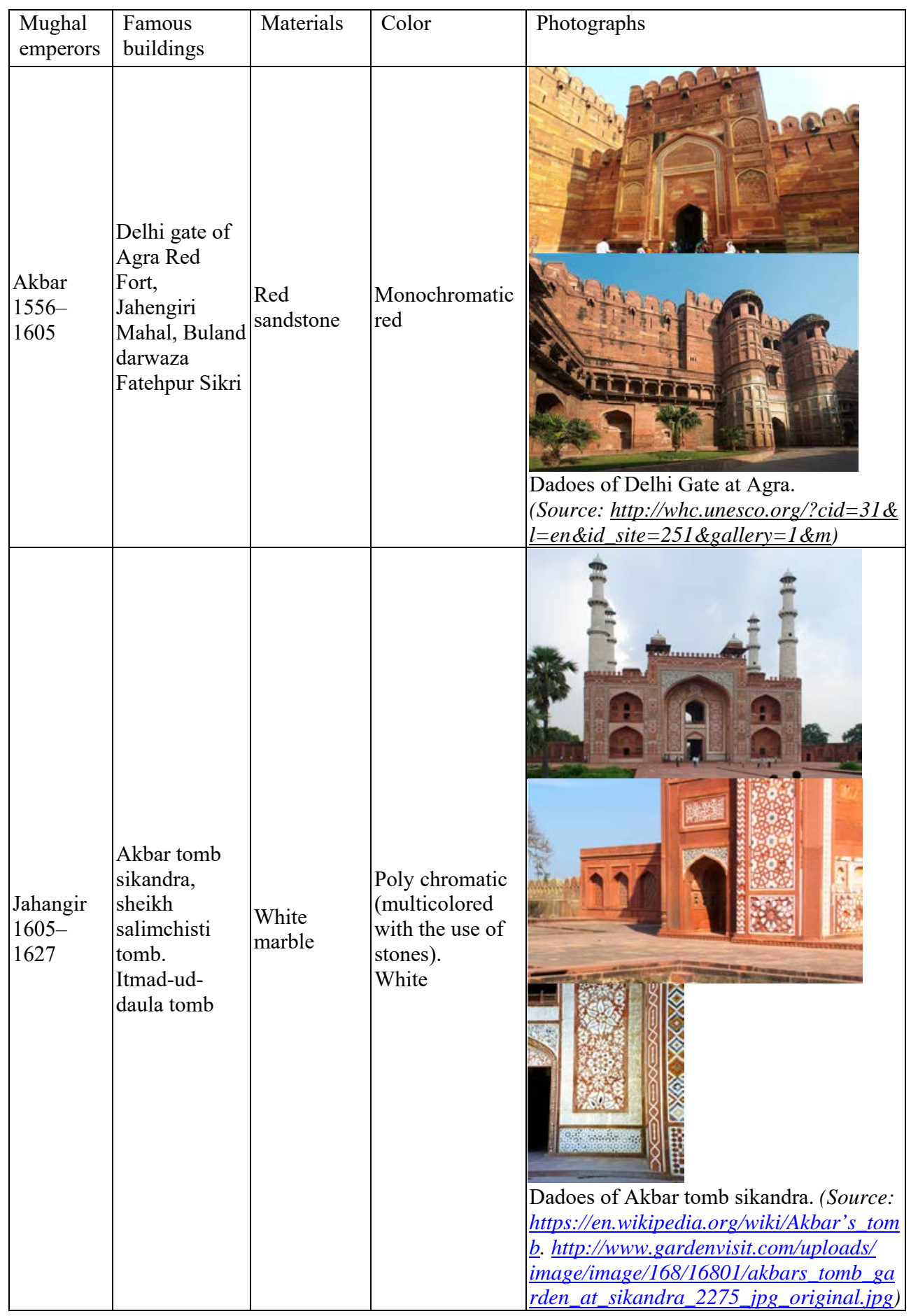


Table 1: Continued.

\begin{tabular}{|c|c|c|c|c|}
\hline \begin{tabular}{|l|} 
Mughal \\
emperors
\end{tabular} & \begin{tabular}{|l} 
Famous \\
buildings
\end{tabular} & Materials & Color & Photographs \\
\hline $\begin{array}{l}\text { Jahangir } \\
1605- \\
1627\end{array}$ & $\begin{array}{l}\text { Akbar tomb } \\
\text { sikandra, } \\
\text { sheikh } \\
\text { salimchisti } \\
\text { tomb. } \\
\text { Itmad-ud- } \\
\text { daula tomb }\end{array}$ & $\begin{array}{l}\text { White } \\
\text { marble }\end{array}$ & $\begin{array}{l}\text { Poly chromatic } \\
\text { (multicolored } \\
\text { with the use of } \\
\text { stones). } \\
\text { White }\end{array}$ & 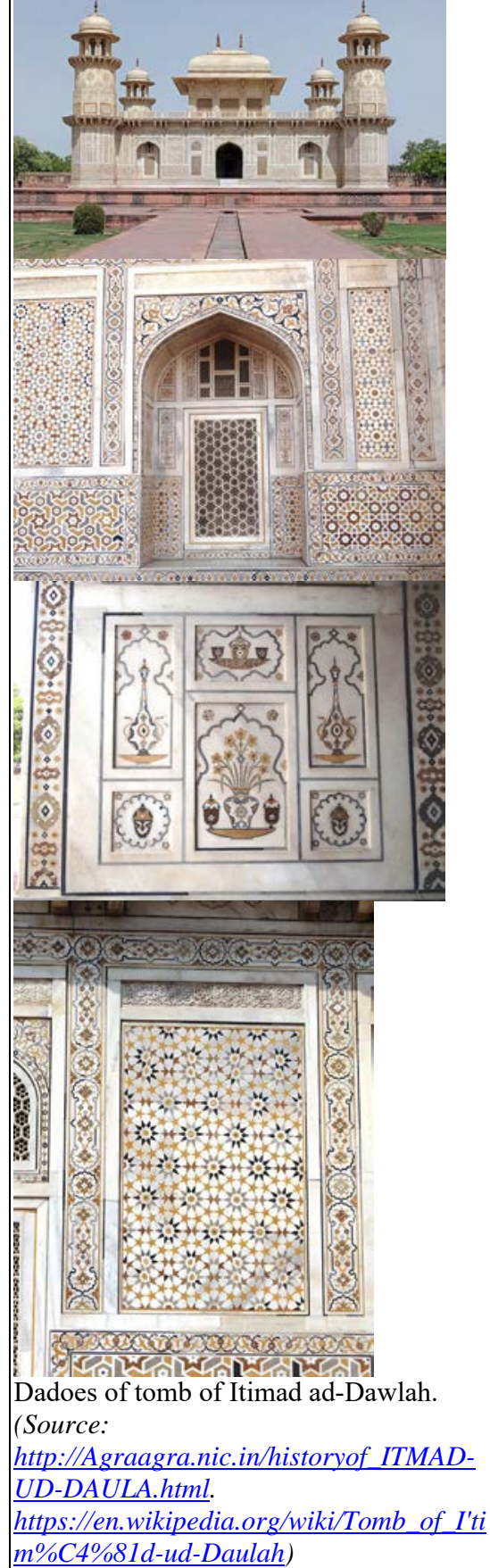 \\
\hline
\end{tabular}


Table 1: Continued.

\begin{tabular}{|c|c|c|c|c|}
\hline $\begin{array}{l}\text { Mughal } \\
\text { emperors }\end{array}$ & $\begin{array}{l}\text { Famous } \\
\text { buildings }\end{array}$ & Materials & Color & Photographs \\
\hline 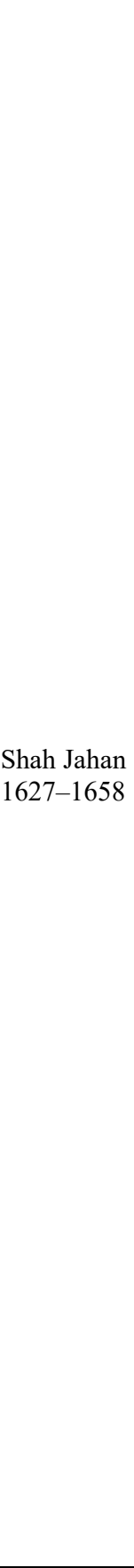 & $\begin{array}{l}\text { Taj Mahal } \\
\text { Zinat al-Masjid } \\
\text { in Daryaganij. } \\
\text { Pearl Mosque } \\
\text { Llahore }\end{array}$ & $\begin{array}{l}\text { White } \\
\text { marble }\end{array}$ & \begin{tabular}{|l|} 
\\
Poly \\
chromatic \\
(multicolored \\
with the use of \\
stones). \\
White
\end{tabular} & (Source: \\
\hline
\end{tabular}


Table 1: Continued.

\begin{tabular}{|c|c|c|c|c|}
\hline $\begin{array}{l}\text { Mughal } \\
\text { emperors }\end{array}$ & \begin{tabular}{|l|} 
Famous \\
buildings
\end{tabular} & Materials & Color & Photographs \\
\hline $\begin{array}{l}\text { Shah Jahan } \\
1627-1658\end{array}$ & 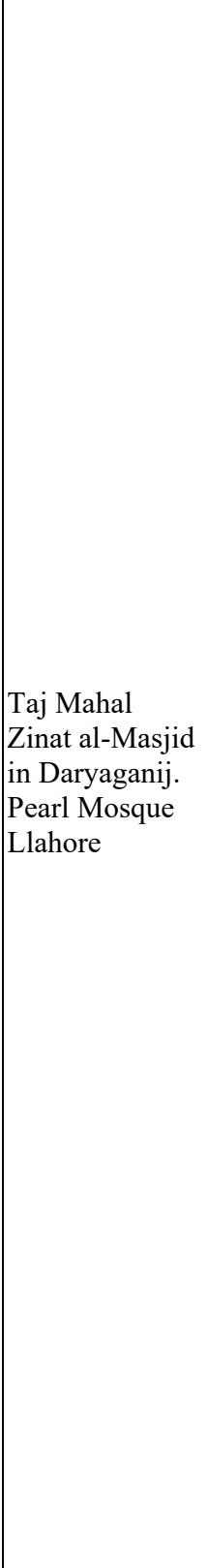 & $\begin{array}{l}\text { White } \\
\text { marble }\end{array}$ & $\begin{array}{l}\text { Poly } \\
\text { chromatic } \\
\text { (multicolored } \\
\text { with the use of } \\
\text { stones). } \\
\text { White }\end{array}$ & (1) \\
\hline
\end{tabular}


Table 1: Continued.

\begin{tabular}{|l|l|l|l|l|}
\hline $\begin{array}{l}\text { Mughal } \\
\text { emperors }\end{array}$ & $\begin{array}{l}\text { Famous } \\
\text { buildings }\end{array}$ & Materials & Color & Photographs \\
\hline $\begin{array}{l}\text { Aurangzeb } \\
1658-1707\end{array}$ & $\begin{array}{l}\text { Badshahi } \\
\text { Mosque, Lahore }\end{array}$ & $\begin{array}{l}\text { Red } \\
\text { brick and } \\
\text { plaster }\end{array}$ & $\begin{array}{l}\text { Monochromatic } \\
\text { red }\end{array}$ & \\
\end{tabular}

\section{CONCLUSIONS}

Mughal decorative art of dado ornamentation is one of the remarkable features of Mughal architecture that displayed their refined artistic sense in the form of beautiful designs blended into vibrant colors and mosaics throughout the Indian subcontinent. This particular ornamentation started with simple designs and bold colors during the Babar period and flourished indigenously during the Humayun and Akbar reigns. The designs transformed into complex integration of flowing lines with the introduction of sophisticated materials like marble, glazed tiles etc. The dado ornamentation during the Shah Jahan reign developed into finest form with the use of white marble and precious or semi-precious stones with intricate designs and deteriorated with the decline during Aurangzeb period. The dado ornamentation like all other decorative arts is influenced from Islamic, Persian and local techniques that transformed into unique Mughal style during their rule according to their refined taste of architecture.

\section{REFERENCES}

[1] Brown, P., Indian Architecture, 1st ed., D.B. Taraporevala Sons: Bombay, 1942.

[2] Nath, R., History of Decorative Art in Mughal Architecture, 1st ed., Motilal Banarsidass: Delhi, 1976.

[3] Baldry, A., Modern Mural Decoration, 1st ed., G. Newnes: London, 1902.

[4] Sharma, R., Mughal seed in modern architectural decoration. Bonfring International Journal of Industrial Engineering and Management Science, 2(4), pp. 112-116, 2012. 
[5] Beach, M. \& Chandra, P., The Tuti-nama of the Clevel and Museum of Art and the Origins of Mughal Painting, Artibus Asiae, 40(1), p. 81, 1978.

[6] Smith, V., A history of fine art in India and Ceylon, 1st ed., Clarendon Press: Oxford, 1911.

[7] Nath, R., Colour Decoration in Mughal Architecture, 1st ed., Bombay, 1970.

[8] Gharipour, M. \& Schick, I, Calligraphy and Architecture in the Muslim World, 1st ed.

[9] Godard, A., The Art of Iran, 1st ed., Praeger: New York, 1965.

[10] Gascoigne, B., A Brief History of the Great Moghuls, 1st ed., Robinson: London, 2002.

[11] Nath, R., Architecture of Fatehpur Sikri, 1st ed., Abhinav Publ.: New Delhi, 1988.

[12] Jahangir, Rogers, A. \& Beveridge, H., The Tūzuk-i-Jahāngīrī, 1st ed., Munshiram Manoharlal: Delhi, 1968.

[13] Sarkar, J., Glimpses of Mughal Architecture, 1st ed., J.J. Bhabha: Bombay, 1954.

[14] Klingelhofer, W., The Jahangiri Mahal of the Agra Fort: expression and experience in early Mughal architecture. Muqarnas, 5, p. 153, 1988.

[15] Mitchell G. \& Currim, M., The Majesty of Mughal Decoration, 1st ed., Thames \& Hudson: London, 2007.

[16] Willis, M., Begley, W. \& Desai, Z, Taj Mahal: The illumined tomb: An anthology of seventeenth-century Mughal and European documentary sources. Pacific Affairs, 64(3), p. 426, 1991.

[17] Begley, W. \& Desai, Z., Taj Mahal, 1st ed., Aga Khan Program for Islamic Architecture: Cambridge, MA, 1989.

[18] Schimmel, A. \& Waghmar, B., The Empire of the Great Mughals, 1st ed., Reaktion Books: London, 2004.

[19] Ebba, K., The Baluster Column, 1st ed., 1982. 